\title{
O PAPEL DA FIFA FAN FESTTM NA COPA DO MUNDO DA ÁFRICA DO SUL
}

\author{
Fernando Borges* \\ Université Panthéon-Assas - França
}

Resumo: Em 2010, pela segunda vez a FIFA promoveu o evento FIFA Fan Fest ${ }^{\mathrm{TM}}$ no país que sediou a Copa do Mundo, e pela primeira vez criou uma versão internacional do evento em grandes cidades ao redor do mundo. O presente trabalho faz uma descrição das FIFA Fan Fests ${ }^{\mathrm{TM}}$, tendo em conta a sua forma organização, a interação do público, a International Fan Fest ${ }^{\mathrm{TM}}$ e formas alternativas do mesmo evento. Essa descrição é feita colocando o evento dentro do quadro teórico dos megaeventos esportivos e as transformações nas quais estão inseridos.

Palavras-chave: África do Sul, Copa do Mundo, FIFA Fan Fest ${ }^{\mathrm{TM}}$, futebol.

Abstract: In 2010, for the second time FIFA organized the FIFA Fan Fest ${ }^{\mathrm{TM}}$ in the country that hosted the World Cup, and for the first time created a international version of the event in big cities over the world. The present paper describes the FIFA Fan Fest ${ }^{\mathrm{TM}}$, taking account their organization model, the public interaction, the International Fan Fest ${ }^{\mathrm{TM}}$ and the alternatives forms of the same event. This description is done framing the event with mega-events theoretical approach and the cultural changes within they are.

Keywords: FIFA Fan Fest ${ }^{\mathrm{TM}}$, football, South Africa, World Cup.

\section{Introdução}

A Copa do Mundo de 2006, disputada na Alemanha, teve alguns momentos marcantes, como a cabeçada de Zidane a Materazzi, a eleição de um

* Doutorando em Ciências da Informação e Comunicação.

Horizontes Antropológicos, Porto Alegre, ano 19, n. 40, p. 201-230, jul./dez. 2013 
jogador de defesa, Fabio Cannavaro, como melhor da competição, o tetracampeonato italiano e, no que diz respeito a este trabalho, a criação das FIFA Fan Fests ${ }^{\mathrm{TM}} .{ }^{1}$ Em 2002, durante o Mundial disputado na Coreia do Sul e Japão, se tornou popular nos centros das cidades que um grande número de pessoas assistisse aos jogos em espaços públicos. Isso aconteceu de maneira informal, sem o controle das entidades oficiais e sem uma perspectiva de marketing, por isso, para 2006, a Federação Internacional de Futebol Associado (FIFA) resolveu entrar em cena e criar a Fan Fest ${ }^{\mathrm{TM}}$. São espaços com tela gigante $\mathrm{e}$ acesso livre ao público para assistir aos jogos do Campeonato do Mundo. O sucesso na Alemanha foi tamanho, que, segundo a FIFA, cerca de 18 milhões de pessoas frequentaram as FIFA Fan Fests ${ }^{\mathrm{TM}}$, seis vezes o número do público nos 12 estádios da competição (FIFA, 2010a).

O sucesso dessa iniciativa fez com que a FIFA decidisse aumentar o tamanho do projeto. Para o Mundial da África do Sul, além de organizar Fan Fests $^{\mathrm{TM}}$ nas cidades-sedes, a FIFA decidiu organizar a International Fan Fest ${ }^{\mathrm{TM}}$, em que cidades ao redor do mundo também receberiam a infraestrutura dos telões gigantes para transmitir os jogos da copa. As cidades escolhidas foram: Berlim, Cidade do México, Paris, Londres, Roma, Rio de Janeiro e Sydney. ${ }^{2}$

Entretanto, não apenas a FIFA aproveita o sucesso das transmissões públicas de jogos de futebol. A União Europeia de Futebol Associado (UEFA), ao organizar o seu torneio continental na Áustria e Suíça, o Euro 2008, assim como a recente mudança da final da Champions League a ser disputada nos sábados, também permitiu que uma similar iniciativa fosse feita para tal evento (UEFA Champions Festival..., 2010).

Para entender a repercussão das Fan Fests ${ }^{\mathrm{TM}}$ é preciso enquadrá-las não só dentro do fenômeno dos megaeventos, mas também no processo de higienização e controle dos estádios. Os megaeventos têm se reproduzido com maior frequência e com o cenário da globalização têm ganhado ainda mais força, chegando a produzir um padrão discursivo próprio. Para o intuito deste trabalho dá-se o destaque para os megaeventos esportivos. O processo de mudanças

\footnotetext{
A designação de "trade mark" se explica pois é uma marca registrada pela FIFA.

2 Aparentemente houve algum problema com Londres e a FIFA Fan Fest ${ }^{\mathrm{TM}}$ não aconteceu na Inglaterra. $\mathrm{O}$ site da FIFA, que inicialmente indicava a capital inglesa como uma das cidades a receber o evento, não fornece nenhuma informação oficial sobre a retirada de Londres do mapa com os locais que receberam a Fan Fest ${ }^{\mathrm{TM}}$, embora a cidade ainda apareça em alguns textos promocionais.
}

Horizontes Antropológicos, Porto Alegre, ano 19, n. 40, p. 201-230, jul./dez. 2013 
dos estádios é fundamental para entender a diferença de comportamento dos torcedores e as transformações espaciais em torno de um jogo de futebol. Os estádios têm diminuído de tamanho e têm se tornado um espaço cada vez mais controlado por policiais, agentes de segurança privada e câmeras de segurança (Gaffney; Mascarenhas, 2005/2006). Essas mudanças acabam por influenciar a estrutura do esporte.

Incluído nessas transformações da prática esportiva é que se justifica o estudo das FIFA Fan Fests ${ }^{\mathrm{TM}}$. Elas trazem uma nova forma de assistir e viver o jogo, longe dos estádios, algo impensável a uma prática esportiva, mas que se explica com o apoio das novas tecnologias e as novas formas discursivas dos megaeventos. Outro fator relevante é que o financiamento e patrocínio que permite a popularização de tais eventos é feito por grandes companhias transnacionais - atores essenciais para entender a globalização (Bauman, 1999; Featherstone, 1990), a mercantilização da cultura (Featherstone, 1991) e a comercialização do esporte (Horne, 2006).

Sendo as FIFA Fan Fests ${ }^{\mathrm{TM}}$ um fenômeno novo, o presente trabalho tem como objetivo principal fazer uma descrição das mesmas, mas sem deixar de lado uma reflexão crítica sobre o assunto. A recolha do material para esse estudo foi feita através de uma observação participante na África do Sul, no período da Copa do Mundo de 2010, entre os dias 11 de junho e 11 de julho sendo que no dia da final, a partida foi acompanhada na Fan Fest ${ }^{\mathrm{TM}}$ de Paris. O foco principal será nos espaços da África do Sul, tendo a descrição sobre a Fan Fest ${ }^{\mathrm{TM}}$ francesa um caráter comparativo e informativo.

Os recintos visitados e que serviram como base de pesquisa foram as FIFA Fan Fests ${ }^{\mathrm{TM}}$ de Rustemburg, Durban, Cidade do Cabo e de Sandton, em Johanesburgo, em que estive presente em um jogo no primeiro, dois no segundo, um no terceiro e nove no último. Foram realizadas 26 entrevistas com pessoas que assistiam aos jogos nos recintos e com os dois responsáveis pela gestão da FIFA Fan Fest ${ }^{\text {TM }}$ de Johanesburgo, complementadas com informações do material disponibilizado pela FIFA.

A realização das entrevistas foi uma dificuldade metodológica encontrada. Pelas características dos locais - barulho, muita circulação de pessoas - e pela circunscrição do tempo em torno do jogo de futebol, que limitava que as entrevistas fossem feitas no pré ou pós-jogo e no intervalo das partidas, apesar de ir contra as recomendações (Travancas, 2006), as entrevistas não foram tão 
longas quanto se gostaria, mas sempre que o entrevistado permitia, a conversa era alongada.

Neste artigo, em uma primeira parte, vamos ver como os megaeventos estão relacionados ao esporte. Em seguida, farei uma descrição da FIFA Fan Fest ${ }^{\mathrm{TM}}$ na África do Sul, que se completará com uma reflexão sobre as International Fan Fests ${ }^{\mathrm{TM}}$ e tipos alternativos de fan fests.

\section{Os megaeventos e o esporte}

Estudar o esporte tem se mostrado bastante importante para a compreensão de eventos sociais, com possibilidade de análise segundo diferentes correntes de pensamento (Giulianotti, 2005). Da mesma maneira, a importância dos megaeventos pode ser entendida pelas diferentes abordagens de estudo possíveis, como eventos e cerimônias ritualizadas, espetáculos globais comercializados, a expressividade e os quotidianos das pessoas, o papel e a simbologia masculina, dentre outros (Horne; Manzenreiter, 2006). Analisando essas temáticas, podemos dizer, resumidamente, que o evento esportivo engloba todas elas de alguma maneira.

Segundo Maurice Roche (2000, p. 1, tradução minha), os megaeventos são "eventos culturais (incluindo comerciais e esportivos) em larga escala com um caráter dramático e apelo popular massivo ao nível internacional". Ao que pode se completar, o evento é "mega" porque é descontínuo, internacional, fora do comum e grande. Mas sobretudo tem a capacidade de enviar uma mensagem promocional para milhões de pessoas pela TV ou outros meios de comunicação (Roberts, 2004, p. 108 apud Horne; Manzenreiter, 2006).

Apesar de terem uma curta duração, os megaeventos têm efeitos duradouros no que diz respeito ao que acontece antes e depois da sua realização. Eles são percebidos como algo com estatuto fora do comum, baseado justamente na sua grandeza, no seu ciclo temporal e nos seus impactos. Ao mesmo tempo, os megaeventos são muito contraditórios, mas sem dúvida ao analisá-los é possível ver como as suas consequências são pró-hegemônicas (Roche, 2003).

Os megaeventos surgiram no final do século XIX, no qual se destacam primeiramente as Exposições (Expos) Mundiais e os eventos esportivos como os Jogos Olímpicos e a Copa do Mundo de Futebol. Hobsbawm destacou que durante esse período, em que nações e impérios estavam sendo construídos

Horizontes Antropológicos, Porto Alegre, ano 19, n. 40, p. 201-230, jul./dez. 2013 
nos países ocidentais industrializados, as Expos e os eventos esportivos eram fundamentais para a "invenção de tradições" (Roche, 2003, p. 100).

De acordo com Roche (2003), o advento e popularização da televisão também foram fundamentais para as mudanças sofridas pelos megaeventos. Para ele, essas transformações deram mais destaque aos eventos esportivos em detrimento às Expos Internacionais, porque os primeiros puderam com maior eficiência penetrar nas vidas, memórias, sonhos e no tempo dos públicos de massa, uma vez que eles são mais capazes de dramatizar o presente em forma de um media event, como salientado por Dayan e Katz (1992).

A importância dos megaeventos vem crescendo desde os Jogos Olímpicos de Los Angeles em 1984, quando a competição gerou lucro a seus organizadores pela primeira vez desde 1932 (Colvile, 2004). O crescimento desses eventos se dá principalmente por três motivos: o desenvolvimento tecnológico na comunicação de massa e via satélite, a formação de uma aliança entre empresas de mídia e organizações esportivas, além de ter se tornado um sinônimo para a promoção de cidades e regiões (Horne; Manzenreiter, 2006).

Na nossa modernidade tardia, os megaeventos esportivos ainda têm uma importante função. Tendo em vista os processos vigentes de individualização, midiatização e globalização que vêm dificultando a manutenção de identidades nacionais e individuais (Hall, 2006), esses eventos podem ter uma função social e pessoal importante. Uma vez que essas dificuldades advêm da compressão e da quebra de estruturas tradicionais de espaço e tempo, os megaeventos esportivos oferecem a oportunidade de participação em projetos coletivos, contribui para uma estruturação do tempo com base nos seus ciclos (no caso da Copa do Mundo, de quatro em quatro anos, sem mencionar nas eliminatórias) e possibilita diversas formas de ação social, nem que seja ao organizar um churrasco para assistir a um jogo. No entanto, se por um lado eles podem contribuir, por outro é preciso pagar essa contribuição com uma postura passiva de espectador e com uma ideologia do consumo (Roche, 2003, p. 109).

É preciso ainda considerar o papel dos Estados nacionais na organização dos megaeventos. O amadurecimento desses eventos aconteceu em paralelo ao desenvolvimento dos Estados neoliberais, e enquanto se diz que a força dos governos está cada vez menor, é curioso notar o investimento feito em época de candidaturas. O esforço político, a utilização de celebridades nacionais em projetos, as promessas de infraestrutura feitas dão a medida de como sediar um evento desses é importante para o Estado, e afinal a "mão de ferro" pode 
não mais existir, mas quando se faz necessário, ele ainda determina o caminho a seguir (Horne; Manzenreiter, 2006).

Para os governos que se candidatam, os legados deixados por esses eventos são os seus maiores atrativos, embora seja um dos fatores mais difíceis de mensurar. Quando se está planejando um megaevento, normalmente se subvaloriza os gastos a serem feitos e sobrevalorizam-se os benefícios (Horne; Manzenreiter, 2006; Matheson, 2006). Também não é pouco comum que os prazos e orçamentos iniciais divirjam dos anunciados. Além disso, a organização é feita por instituições privadas que se imputam o direito de reservar grande parte das informações, embora muitas vezes utilizem o dinheiro público como investimento.

Enquanto as vantagens econômicas trazidas são bastante questionáveis, o impacto cultural nas comunidades que recebe o evento é imenso. Apesar de todo o risco financeiro, os governos de vários países estão dispostos a apostar em receber um megaevento para poder atrair veículos de mídia nacionais e internacionais, conseguindo o reconhecimento para o local-sede. Devido à variedade de interesses entre comitês locais, governos nacionais, organizações esportivas internacionais e patrocinadores transnacionais, os megaeventos devem ser abordados de maneira multidisciplinar e com diferentes propósitos. Roche (2000), fazendo uso de tal método, pode mostrar como as elites se aproveitam dos megaeventos para promover ideologias dominantes (Horne; Manzenreiter, 2004).

A cultura pós-moderna permite que pessoas, capitais e imagens circulem velozmente, além de comprimir e romper fronteiras de tempo e espaço. Para se diferenciar da modernidade, quando havia uma clara separação entre a audiência e os atletas, na cultura pós-moderna os espectadores também fazem parte do show: mascotes se unem com a torcida, e pessoas da plateia são convidadas ao campo para competições no intervalo do jogo (Horne, 2006, p. 176). No seu material, a FIFA define como World Cup Experience assistir aos jogos presencialmente nos estádios; visitar uma das Fan Fests ${ }^{\mathrm{TM}}$ na África do Sul; ou experimentar o ambiente de uma Copa do Mundo numa das International Fan Fests ${ }^{\text {TM }}$ (FIFA, 2010b). Ao não mencionar vivências comuns como estar com amigos e torcer por sua seleção e concentrar a experiência de Copa do Mundo em torno daquilo que controla, a FIFA mostra o seu caráter centralizador. Além disso, ela deixa claro o papel duplo do público que, ao mesmo 
tempo, é necessário para vender o espetáculo esportivo e serve como alvo aos patrocinadores do evento, seja nos estádios ou nas Fan Fests ${ }^{\mathrm{TM}}$.

Pelas palavras do presidente do comitê organizador, Danny Jordan, podemos ver como era importante a divulgação e sucesso da Fan Fest ${ }^{\mathrm{TM}}$ :

We have always wanted the 2010 FIFA World Cup to touch the lives of as many South Africans as possible. The FIFA Fan Fest will provide an opportunity for millions of our people to watch the matches in a festival environment for free and will also provide an opportunity for small businesses and our musical talents to benefit from this event. (FIFA, 2009). ${ }^{3}$

Assim, com essa iniciativa se possibilita que muitos assistam aos jogos gratuitamente, aumentando o alcance das pessoas atingidas por essa experiência de Copa do Mundo, e, dessa maneira, permitindo também que sejam expostas às marcas divulgadas.

\section{FIFA. Fan Fest'TM}

De acordo com Jessica Lehr, representante da FIFA na Fan Fest ${ }^{\mathrm{TM}}$ de Sandton que entrevistei, o objetivo principal da FIFA ao organizar uma Fan Fest $^{\mathrm{TM}}$ era reproduzir uma atmosfera de estádio, com o mesmo tipo de torcedores, segurança e conforto. No guia oficial com informações para os visitantes das Fan Fests ${ }^{\mathrm{TM}}$ da África do Sul, o texto de destaque era:

The FIFA World Cup ${ }^{\mathrm{TM}}$ is about more than what is happening in the stadiums - it is also about meeting new people, and being involved in the biggest party in the world. The best place, outside the stadium, to experience the carnival atmosphere over the 31 days of the tournament will be the ten FIFA Fan Fests ${ }^{\mathrm{TM}}$ across South Africa. (FIFA, 2010c).

Criadas para a Copa do Mundo de 2006 na Alemanha, as FIFA Fan Fests $^{\mathrm{TM}}$ são organizadas em parceria entre a cidade-sede e a FIFA. Para se

\footnotetext{
3 "Nós sempre quisemos que a Copa do Mundo de 2010 tocasse a vida do maior número de sul-africanos possíveis. A FIFA Fan Fest vai ser uma oportunidade para milhões de pessoas do nosso país assistirem aos jogos num ambiente de festival, de maneira gratuita e que também beneficiará as pessoas com pequenos negócios e com talento musical.” (tradução minha).
}

Horizontes Antropológicos, Porto Alegre, ano 19, n. 40, p. 201-230, jul./dez. 2013 
enquadrar como uma área oficial da FIFA é preciso ter os seguintes princípios básicos: entrada gratuita para um local seguro a todos os visitantes; todos os jogos são transmitidos ao vivo; os espaços têm que reproduzir a atmosfera de um estádio de futebol; telões gigantes de grande qualidade e sistemas de som e de luz que garantam uma ótima experiência ao assistir ao jogo; a FIFA Fan Fest $^{\mathrm{TM}}$ é um evento de dia inteiro; antes e depois das transmissões dos jogos o palco e tela gigante são usados para entretenimento; produtos, comidas e bebidas licenciadas estão disponíveis no local; as FIFA Fan Fests ${ }^{\mathrm{TM}}$ são mais do que assistir a futebol, eles são uma verdadeira experiência de fã (FIFA, 2010a).

A quantidade de estádios a serem usados na Copa do Mundo da África do Sul é equivalente a das FIFA Fan Fests ${ }^{\mathrm{TM}}$, dez cada um. Dessa maneira, onde havia um estádio, havia uma FIFA Fan Fest ${ }^{\mathrm{TM}}$ : Cidade do Cabo, Pretória, Durban, Port Elizabeth, Bloemfontein, Nelspruit, Polokwane, Rustemburg e duas em Johanesburgo, respeitando a proporcionalidade dos estádios, que eram dois na cidade, o Ellis Park e o Soccer City, como havia a Fan Fest ${ }^{\mathrm{TM}}$ de Sandton e Soweto.

A FIFA Fan Fest ${ }^{\mathrm{TM}}$ de Sandton ficava localizada em um parque, no Innes Free Park, uma grande área verde entre o distrito comercial de Sandton e da township de Alexandra. Tinha a capacidade para receber 20 mil pessoas e ficava a $15 \mathrm{~km}$ do estádio Ellis Park.

A FIFA Fan Fest ${ }^{\mathrm{TM}}$ de Soweto, na township de Rockville, ficou sediada no Elkah Stadium e o Soweto Cricket Club. Tinha a capacidade para 40000 pessoas e ficava a $8 \mathrm{~km}$ de distância do Soccer City.

A FIFA Fan Fest ${ }^{\mathrm{TM}}$ de Cidade do Cabo ficava na praça da Grand Parade, no centro histórico e com vista para um dos símbolos da cidade, a Table Mountain. Tinha a capacidade para receber 25 mil pessoas e ficava a 2,6 km do estádio Green Point.

A FIFA Fan Fest ${ }^{\mathrm{TM}}$ de Pretória era no Centurion Cricket Ground e tinha a capacidade para receber 30 mil pessoas. O local, que disponibilizava lugares sentados ou em pé, já recebeu inúmeros eventos esportivos do país e, além de contar com marcos da cultura local, também recebia a influência estrangeira das várias embaixadas com base na cidade.

A FIFA Fan Fest ${ }^{\mathrm{TM}}$ de Durban era a única da África do Sul que estava localizada nas areias de uma praia. New Beach é a região onde estão localizados os principais hotéis e restaurantes da cidade, junto às águas quentes do Oceano 
Índico - seus principais atrativos. Tinha capacidade para 25 mil pessoas e estava a 3,5 km do estádio Moses Mabhida.

A FIFA Fan Fest ${ }^{\mathrm{TM}}$ de Port Elizabeth ficava no St. George's Park Cricket Stadium, o segundo mais antigo do país. Contava com uma tela maior do que a habitual, com $75 \mathrm{~m}^{2}$ e disponibilizava lugares sentados e em pé. Com capacidade para 25 mil pessoas, a Fan Fest ${ }^{\mathrm{TM}}$ estava a $5 \mathrm{~km}$ de distância do estádio Nelson Mandela Bay. ${ }^{4}$

A FIFA Fan Fest ${ }^{\mathrm{TM}}$ de Bloemfontein ficava no Mangaung Outdoor Sports Centre na township de Rocklands. O local tem a capacidade de receber 20 mil pessoas e está a $12 \mathrm{~km}$ do estádio Free State.

A FIFA Fan Fest ${ }^{\mathrm{TM}}$ de Nelspruit estava situado na Bergvlam High School, um local acostumado a receber grandes eventos, como o Innibos Arts Festival, que costuma atrair 100 mil pessoas. Após alguns melhoramentos, a Bergvlam High School, localizada a $5 \mathrm{~km}$ do estádio Mbombela, se adequou aos parâmetros da FIFA e ficou apta a receber 30 mil fãs.

A FIFA Fan Fest ${ }^{\mathrm{TM}}$ de Polokwane era no Cricket Club da cidade, que tinha 107 anos de idade. Era capaz de receber até 30 mil pessoas e estava localizada a $1,2 \mathrm{~km}$ do estádio Peter Mokaba.

A FIFA Fan Fest ${ }^{\mathrm{TM}}$ de Rustemburg estava situada no Fields College School e contava com um palco independente da tela gigante. O local tinha capacidade para 20 mil pessoas e estava a $15 \mathrm{~km}$ do estádio Real Bafokeng.

Pode-se perceber, tanto pela localização quanto pelo local onde se situavam, que FIFA e os comitês locais estavam se empenhando em fazer das Fan Fests $^{\mathrm{TM}}$ um local que reproduzisse um estádio. Não só algumas delas estavam dentro de recintos de outros esportes, mas também cada uma delas ficava a no máximo 15 quilômetros do estádio mais próximo, o que permitia que o clima de festa levado pelos torcedores que tinha ingressos para o jogo fosse passado também às Fan Fests ${ }^{\mathrm{TM}}$.

A responsabilidade de gerir uma Fan Fest ${ }^{\mathrm{TM}}$ é dividida entre a FIFA e o comitê organizador de cada cidade-sede. Elas se basearam no mesmo modelo usado na Alemanha em 2006, no qual a FIFA fica responsável por fornecer a tela gigante, o palco, o sistema de som e luzes, a mão de obra técnica, a

4 Para se ter de exemplo: http://www.nelsonmandelabay.gov.za/fifaworldcup/Assets/fan-fest-tour/ GreenRoom_FanfestP.html. 
gerência do projeto, o marketing e promoção do evento. As cidades-sedes ficavam responsáveis pelo programa de entretenimento, as comidas e bebidas disponíveis, o conteúdo a ser divulgado nas telas durante os espaços sem jogos, o merchandising disponível, o planejamento de segurança e transporte, o tamanho e localização do espaço e as horas de abertura e encerramento. Os comitês locais tinham essa liberdade desde que sempre obedecendo ao guia de encargos que a FIFA estabelece.

Dessa maneira, os espaços têm certos quesitos a serem respeitados, mas ao mesmo tempo cada cidade tem liberdade para outras questões, como, por exemplo a sua localização, a campanha de marketing em torno da Fan Fest ${ }^{\mathrm{TM}}$ e as atrações culturais. Durban, por exemplo, que compete com Cidade do Cabo como principal destino turístico do país, apostou forte na divulgação de suas vantagens, tendo o slogan "Durban, the warmest place to be", ${ }^{5}$ afinal era inverno na África do Sul, e grande parte dos turistas, vindos do hemisfério norte, estavam em época de verão. Assim, a sua Fan Fest ${ }^{\mathrm{TM}}$ era localizada no ponto de maior movimento dos turistas, além de haver um grande investimento para que as pessoas fossem lá não só com o objetivo de assistir aos jogos, mas também como ponto de encontro entre jovens e fãs com vontade de se divertir. A Fan Fest ${ }^{\mathrm{TM}}$ contava com uma programação musical antes dos jogos, mas também com DJs que após os jogos da noite mantinham o clima de festa entre os visitantes. Além disso, a organização local instalou uma série de pontos de informação turística dentro do recinto para divulgar outras atividades turísticas da cidade.

Mas, apesar de haver esse pequeno grau de diferenciação entre as Fan Fests $^{\mathrm{TM}}$ é possível notar características comuns entre elas no que diz respeito à organização do seu espaço e ao comportamento do público. Por isso, baseada na observação de diferentes recintos, segue uma descrição do que é uma FIFA Fan Fest ${ }^{\mathrm{TM}}$.

A parte fundamental de todas as Fan Fests ${ }^{\mathrm{TM}}$ era a sua tela de $50 \mathrm{~m}^{2}$ e o sistema de som e luz. Ambos eram fornecidos pela FIFA e considerados como essenciais para uma boa experiência do espectador e ideais para assistir

\footnotetext{
5 A tradução seria "Durban, o lugar mais quente para se estar". Sendo que no inglês o "warmest" permite o duplo entendimento como sendo o local com o clima mais ameno em oposição ao frio do inverno de outras cidades, mas também no sentido de acolhedor.
}

Horizontes Antropológicos, Porto Alegre, ano 19, n. 40, p. 201-230, jul./dez. 2013 
aos jogos de futebol. No que diz respeito à emissão dos jogos, a transmissão sempre começava com uma mensagem de boas vindas para a respectiva Fan Fest $^{\mathrm{TM}}$ com as cores e marca da Coca-Cola, uma das patrocinadoras oficiais do evento, e terminava essa abertura com o seu slogan "open your happiness". ${ }^{6}$ Durante o jogo, a tarefa ficava a cargo da South Africa Broadcasting Corporation (SABC), que era a televisão oficial do evento na África do Sul, no entanto, diferente da emissão que ia para a casa dos espectadores, essa era uma produção exclusiva. Do ponto de vista das imagens, contava com todas as disponibilizadas pela empresa responsável por produzir e transmitir todos os jogos, a Host Broadcast Unit (HBU), mas só havia um narrador falando sobre os acontecimentos do jogo em inglês - e nos jogos da África do Sul a narração ia intercalando o inglês com o zulu. No intervalo, não havia comentários, análises ou repetição de imagens, havia primeiro um momento com vídeos promocionais e em seguida algum tipo de entretenimento, na maioria dos casos uma promoção dos patrocinadores do evento, dentre eles, os oficiais, Neo Africa, MTN e Coca-Cola, e outros que ficavam a escolha de cada comitê local. Ao fim do jogo, repetiam-se os vídeos promocionais e o que vinha a seguir dependia do horário do jogo, do dia e do local da Fan Fest ${ }^{\mathrm{TM}}$, uma vez que algumas apostavam mais do que outras na oferta cultural.

As telas e o sistema de som e luz estavam associados a um palco onde aconteciam as atividades culturais e de entretenimento já mencionadas. É interessante notar que mesmo com as grandes dimensões do palco, durante essas ações a tela continuava a ser usada. Se não para transmitir os jogos, para mostrar o público, criando interação e mostrando que mesmo em acontecimentos presenciais existe o hábito de se transmitir e perceber o evento através de uma mensagem audiovisual.

Apesar de cada cidade ter dimensionado a sua Fan Fest ${ }^{\mathrm{TM}}$, podemos dizer que elas se organizavam a partir de dois espaços distintos. O principal era em torno da tela, caracterizado por grandes áreas, de areia, grama ou cimento, onde os espectadores poderiam sentar, ou ficar de pé - de acordo com a lotação e emoção do jogo - para assistir às partidas. De acordo com as possibilidades de cada lugar, eles eram organizados de maneira diferente, ou se aproveitando de pequenas elevações naturais, ou disponibilizando arquibancadas de

6 No Brasil, "abra sua felicidade".

Horizontes Antropológicos, Porto Alegre, ano 19, n. 40, p. 201-230, jul./dez. 2013 
madeira, ou contando com uma grande área plana. Além do espaço para os espectadores, havia sempre uma área VIP que era gerenciada por um dos patrocinadores e a sua entrada estava condicionada a convites do organizador. Esses espaços raramente ficavam muito próximos à tela, mas nunca a ponto da visibilidade ser ruim, tendo ainda um grau de conforto nos acentos e uma disponibilização exclusiva de bebidas e comidas, tal como se fosse um espaço autossuficiente.

O segundo espaço era o da comida e lazer, que ficava em torno da área onde se viam os jogos, e/ou em espaços adjacentes. Nesses lugares havia as barracas de comida - licenciadas pelo comitê organizador local, que variavam de acordo com a cultura culinária da cidade - e de bebida. Tendo uma grande companhia de bebidas como patrocinador oficial, quem comercializava bebidas dentro da Fan Fest ${ }^{\mathrm{TM}}$ era obrigado a comprar seus estoques do mesmo fornecedor e vendê-los todos com o mesmo preço. A parte referente ao lazer eram espaços organizados pelos patrocinadores oficiais do evento com jogos e animações com objetivos de divulgar as suas respectivas marcas e de alguma maneira entreter o público nos períodos em que não havia transmissões.

Seguindo a lógica do consumo, estavam nessa área também as lojas de produtos oficiais da FIFA. Nelas se vendiam desde os uniformes das seleções nacionais até cobertores, passando por roupas de cachorro, casacos, camisas e bolas - tudo sempre com a marca da FIFA. Um dado a ser analisado na venda dos produtos dentro da loja oficial é que, diferentemente a todos os outros comercializados na África do Sul, eles não possuíam taxação de impostos. Em um acordo entre a FIFA e o país organizador da Copa do Mundo é tal como se a loja oficial da FIFA fosse uma zona franca, ou um duty free dentro do território nacional.

A segurança das Fan Fests ${ }^{\mathrm{TM}}$ era feita internamente por empresas particulares e na parte externa pela polícia local. A segurança particular fazia a revista nos espectadores que entravam e mantinha a ordem no local, e os policiais cuidavam dos acessos do lado de fora, do trânsito e, em caso de algum incidente dentro da Fan Fest ${ }^{\mathrm{TM}}$, eles eram chamados se fosse preciso intervenção policial. Além disso, todas as Fan Fests ${ }^{\mathrm{TM}}$ tinham as mesmas proibições estabelecidas para a entrada, que eram, na ordem apresentada na placa: armas; garrafas, copos e latas; material para fazer vídeo e foto para uso comercial; álcool ou drogas; materiais racistas ou xenófobos; bandeiras com dimensões maiores do que 2 × 1,5 m; capacetes de motocicleta; objetos 
que comprometam a segurança pública; comida ou bebida; sprays; fogos de artifício; objetos de barulho, com exceção da vuvuzela; produtos ou ingressos a serem vendidos; animais; e materiais promocionais de empresas. A partir dessa lista fica clara a intenção de coibir a violência, mas com a mesma importância fica a proteção da marca da FIFA e de seus patrocinadores, assim como a obrigação de consumir dentro do espaço das Fan Fests ${ }^{\mathrm{TM}}$. Sobre a segurança, é preciso ainda fazer uma pequena observação: assim como ocorreu com outras questões ao longo da Copa do Mundo na África do Sul, as coisas começaram a funcionar de um jeito, e depois foram se acertando. No que se refere às Fan Fests ${ }^{\mathrm{TM}}$, a segurança é um dos pontos que mais chamou a atenção, nos primeiros quatro dias era possível entrar com comidas, bebidas, garrafas - a fiscalização era menos rigorosa - e era permitido estacionar bem próximo ao local, mas depois a situação se modificou, alcançando os padrões estabelecidos pela FIFA. Dentro ainda da lógica de controle do espaço, o acesso da mídia era feito com base em autorizações e credenciamento prévio para entrar nas FIFA Fan Fests ${ }^{\mathrm{TM}}$.

Como já foi dito anteriormente, cada comitê local tinha liberdade para fazer a programação cultural, assim como estabelecer os horários de abertura e encerramento das Fan Fests ${ }^{\mathrm{TM}}$. Não foi por acaso que esse foi o ponto no qual houve o maior grau de diferenciação. Cada cidade, de acordo com a sua própria agenda política, desenhou objetivos específicos para esses espaços, por isso se pôde ver algumas das Fan Fests ${ }^{\mathrm{TM}}$ funcionando até horas depois do jogo, pois serviam de espaço para encontro de pessoas, discoteca e espaço turístico. Não só a agenda política foi quem definiu isso, mas o clima das cidades também foi determinante, lugares com o clima mais ameno como Cidade do Cabo e Durban puderam criar mais atividades para sua população e para os turistas, enquanto o frio afastava as pessoas em outras localidades.

É interessante notar como as Fan Fests ${ }^{\mathrm{TM}}$ se organizaram de modo a se tornarem estádios, quando nas últimas duas décadas tem se visto uma série de transformações nas estruturas e conceito destes. Gaffney e Mascarenhas (2005/2006) argumentam que os estádios, gradualmente, foram se inserindo na lógica do consumo e do espetáculo, deixando de ser um espaço de socialização, expressão e poder. Com a crescente preocupação com segurança e conforto, os estádios têm se tornado cada vez menores, e mais vigiados. Dessa forma os torcedores estão mais sujeitos a controle, perdendo parte de sua espontaneidade e liberdade. Espaços tradicionais, como os terraces na

Horizontes Antropológicos, Porto Alegre, ano 19, n. 40, p. 201-230, jul./dez. 2013 
Inglaterra, e a geral do Maracanã, vão sendo extintos e remodelados em nome de um padrão de conforto, ditado pelas federações internacionais, tirando o que eles antes tinham de singular para se tornarem espaços padronizados. Isso se insere em uma lógica onde o estádio é assimilado a outros espaços comerciais e previsíveis, como centros comercias, salas de cinema e a sala de TV - domínios do individualismo e passividade, que servem de grande valia ao capital.

Horne (2006) afirma que o aumento de gastos com bens como férias, esporte e lazer são características da sociedade de consumo. Ele completa que na nossa atual fase de desenvolvimento capitalista, a commodity vem sendo desmaterializada, dando espaço para o consumo de eventos culturais, patrimônios históricos e eventos esportivos, o que se pode resumir como experiencial commodities. São, justamente, megaeventos que permitem a união entre companhias transnacionais, mídia e esporte.

Dessa maneira, não é estranho que todas as Fan Fests ${ }^{\mathrm{TM}}$ sejam em grande parte semelhante umas às outras. Essas mudanças não só afetam a arquitetura dos estádios, elas trazem consequências aos gostos e discursos que se modificam. As Fan Fests ${ }^{\text {TM }}$ estão sob a mesma égide de consumo e espaços transnacionais que rege a organização dos estádios, e inclusive é isso que atrai os seus frequentadores:

Esse aqui é um bom lugar para assistir ao jogo, tem gente em volta, uma tela gigante, dá para celebrar, encontrar outras pessoas, é de graça e tem cerveja perto, enquanto no estádio é muito caro. (Wiil, África do Sul).

Só consegui dois bilhetes para ir aos jogos e por isso resolvi vir até aqui para ver os jogos. Penso que para ver jogo tem que ter ambiente, é tudo sobre a vibração que tá em volta da gente, isso que é importante. (Jurgen, Alemanha).

Os bilhetes foram um dos argumentos apontados para se frequentar a Fan Fest $^{\mathrm{TM}}$. Para a Copa do Mundo de 2010, a FIFA abriu a primeira fase de vendas em fevereiro de 2009, antes mesmo de se saberem as equipes classificadas e os grupos definidos. A compra era feita pela internet em forma de loteria, na qual cada candidato poderia tentar obter ingressos para jogos definidos ou para acompanhar uma seleção específica, caso ela se classificasse, sendo que cada pessoa só poderia adquirir no máximo sete entradas. Outras fases se 
sucederam sempre obedecendo a critérios aleatórios. Além da venda online, quando se aproximou mais a Copa do Mundo, as agências de viagem, associadas às federações nacionais e à FIFA, também passaram a vender bilhetes agregados a pacotes de viagem.

Os ingressos estavam divididos em quatro categorias que se separavam por preço e localização, sendo a categoria um a mais cara, e a quatro a mais barata, porém ela só estava disponível à população sul-africana. Na primeira fase, os bilhetes custavam 120,100, 80 e 20 dólares americanos respectivamente. Para a fase seguinte os preços aumentaram, chegando a US\$ 400 a entrada para final em categoria três.

O preço do ingresso está diretamente ligado às transformações sofridas pelos estádios nessas últimas décadas. As suas capacidades de público vieram a diminuir e os custos de suas construções aumentaram, dessa forma, para resolver a equação, a solução tem sido aumentar o preço dos bilhetes. Tem sido assim nas principais ligas europeias e também no Mundial.

Eu consegui comprar cinco ingressos. Foram todos antes de saber quem ia jogar, por isso tenho jogos de várias seleções. Mas como não tenho ingresso para o jogo da Inglaterra de hoje resolvi vir até aqui assistir. (Stuart, Inglaterra).

Escolhi os meus ingressos não pela minha seleção, mas pela qualidade dos jogos. Eu e meus amigos queríamos ver Messi jogar, a Holanda, a Espanha, o Brasil, Kaká, e por isso não compramos todos da primeira fase, só o da estreia e o terceiro, e por isso estamos aqui hoje. (Thomas, Alemanha).

Como nós não pudemos ir ao estádio, nós viemos para cá porque não há atmosfera como estar num espaço aberto com um grande público. O problema é que eles disponibilizam mais ingressos para as pessoas de fora do que para os sul-africanos. Se nós quisermos ir ao jogo temos que entrar em uma fila de três dias, o que é impossível para quem trabalha. (Riyaaz, África do Sul).

Tendo em vista as mudanças apresentadas nos estádios, a transformação no gosto e expectativa das pessoas no que diz respeito a uma partida de futebol, é bastante compreensível a vontade da FIFA de aproximar a experiência de uma Fan Fest ${ }^{\mathrm{TM}}$ com a ida a um estádio de futebol. As características apresentadas por Gaffney e Mascarenhas (2005/2006) de consumo e passividade se enquadram bastante bem dentro da lógica da Fan Fest ${ }^{\mathrm{TM}}$. 


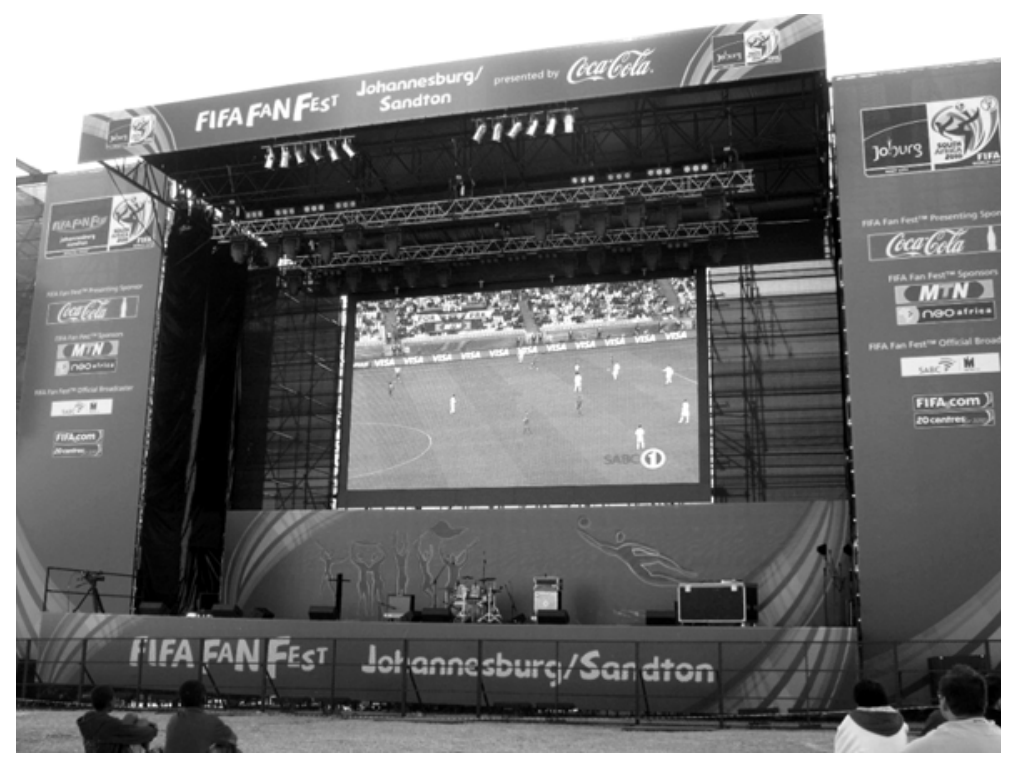

Figura 1. Tela gigante da Fan Fest ${ }^{\mathrm{TM}}$.

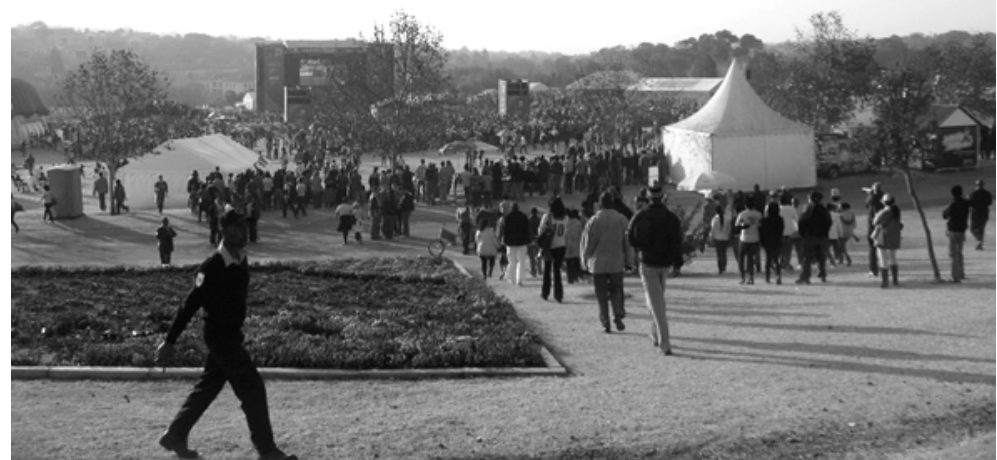

Figura 2. Grande público para assistir a África do Sul e França na Fan Fes ${ }^{\mathrm{TM}}$ de Sandton.

Horizontes Antropológicos, Porto Alegre, ano 19, n. 40, p. 201-230, jul./dez. 2013 


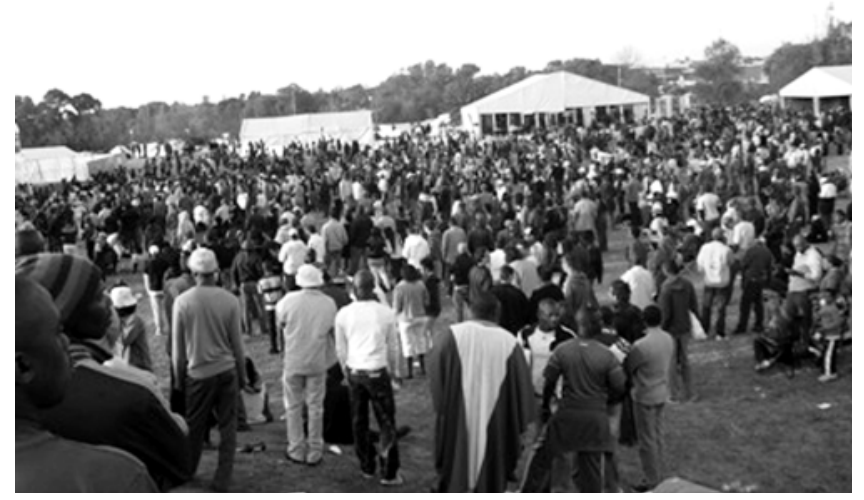

Figura 3. Jogo entre Nigéria e Argentina na primeira fase da Copa do Mundo. As seleções africanas atraíam grande torcida, e o público ainda estava animado com o evento. Após a eliminaccão da áfrica do Sul, o público perdeu parte do interesse.

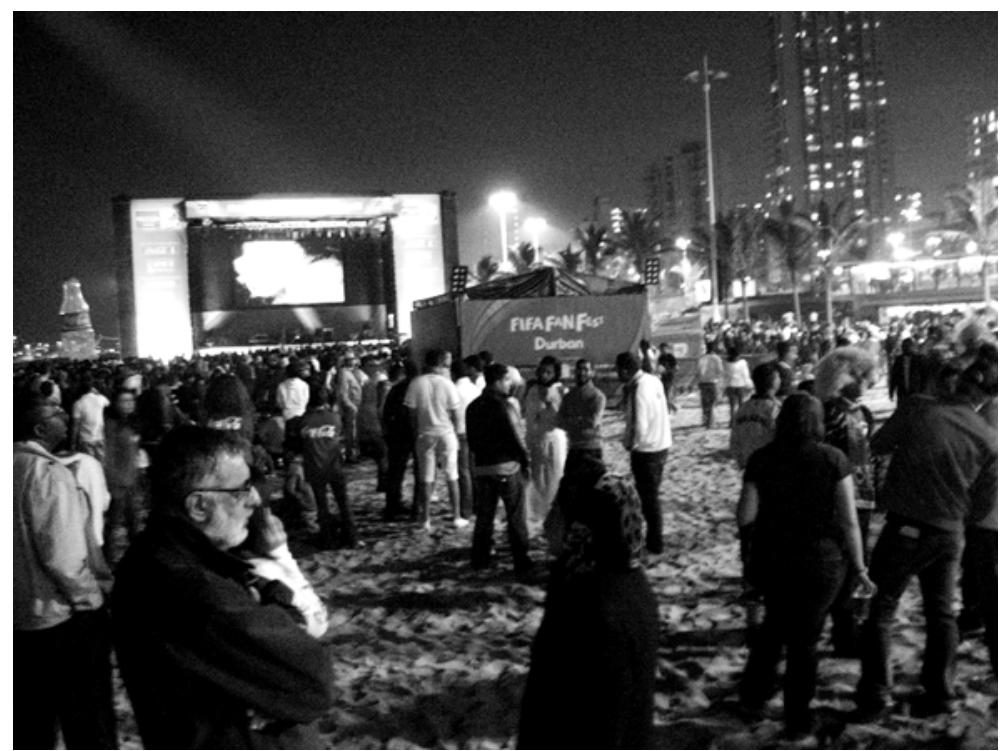

Figura 4. Fan Fes ${ }^{\mathrm{TM}}$ em Durban. Cheia, apesar de ser um jogo sem grande interesse entre Espanha e Chile. Nem todos assistiam ao jogo, mas era um espaco de encontro entre as pessoas da cidade e turistas.

Horizontes Antropológicos, Porto Alegre, ano 19, n. 40, p. 201-230, jul./dez. 2013 


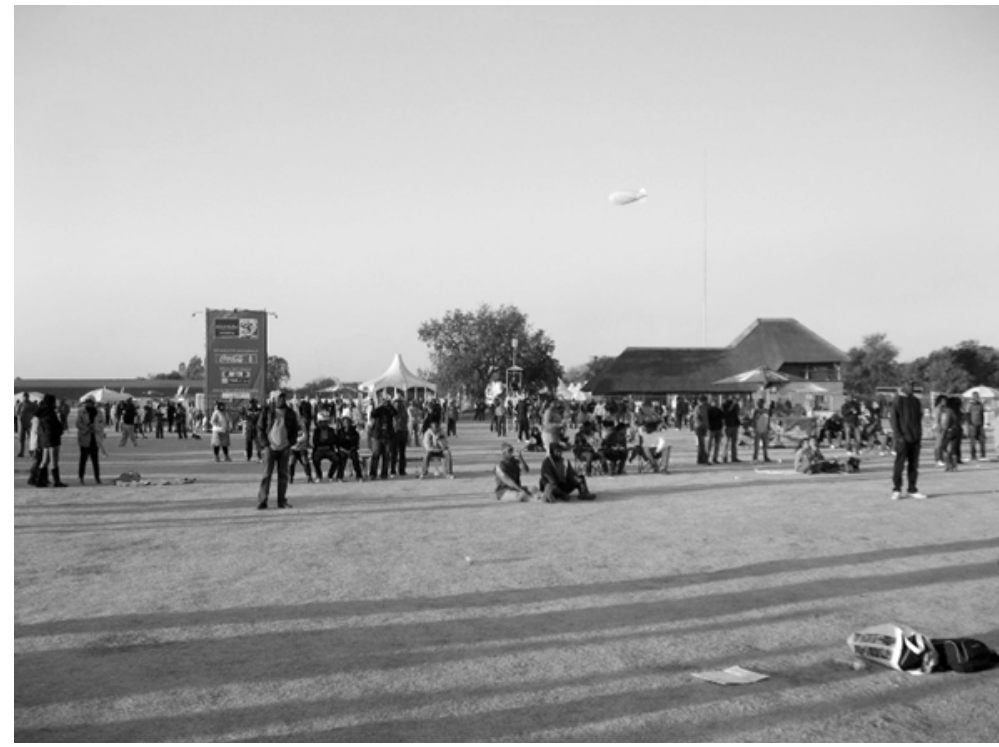

figura 5. Alguns jogos e cidades tinham mais dificuldades em atrair público. Fan Fest ${ }^{\mathrm{TM}}$ em Rustemburg.

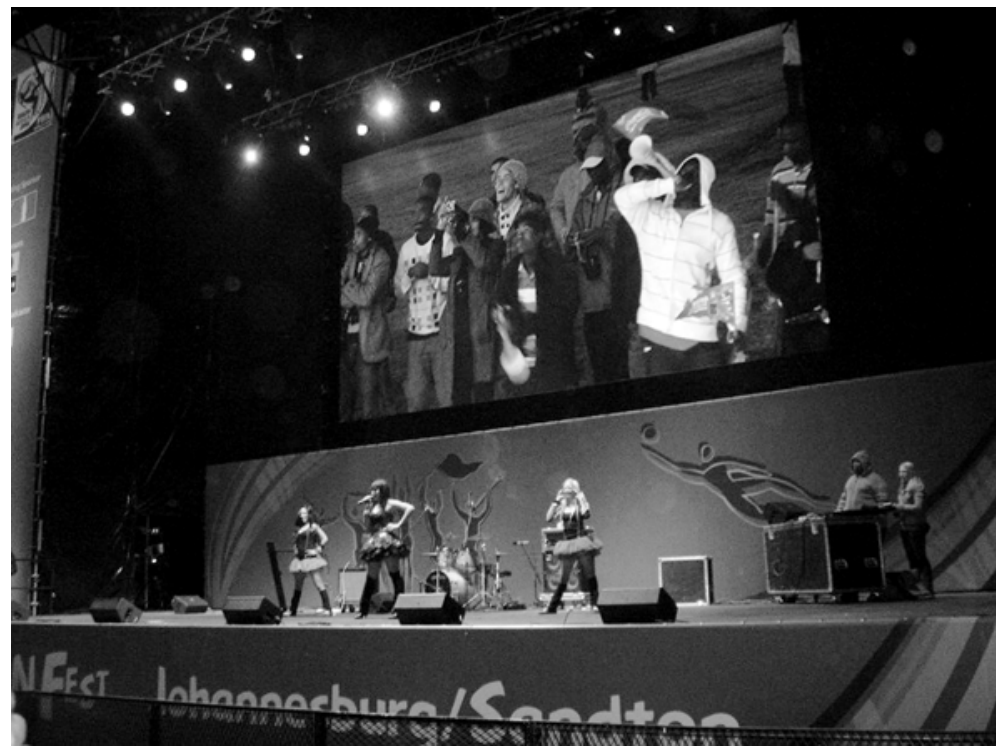

figura 6. Show musical de um grupo local na fan Fest ${ }^{\mathrm{TM}}$ de Sandton, o telão é usado para mostrar o público.

Horizontes Antropológicos, Porto Alegre, ano 19, n. 40, p. 201-230, jul./dez. 2013 


\section{Interação do público}

Ao analisar a performance masculina em bares durante a transmissão televisiva de jogos de futebol, Édison Gastaldo (2005) pôde perceber que esse processo é uma importante forma de sociabilização nacional. Para tanto, ele foi buscar o conceito a Georg Simmel, para quem a sociabilidade é uma forma de interação na qual os participantes se mostram a um só tempo interessados e descomprometidos, autonomizando suas atuações no sentido de evitar qualquer demonstração de um interesse objetivo nos assuntos tratados.

Embora Gastaldo foque o seu trabalho nas questões da identidade masculina e nas relações jocosas entre as pessoas - assuntos que não são relativos ao presente estudo -, podemos usá-lo como base para analisar a interação das pessoas numa FIFA Fan Fest ${ }^{\mathrm{TM}}$, uma vez que se trata também de um espaço público com recepção via televisão de um jogo de futebol. Da mesma forma, as Fan Fests ${ }^{\mathrm{TM}}$ têm como proposta ser um espaço de sociabilização entre torcedores do país-sede, nesse caso a África do Sul, assim como turistas do resto do mundo que não tenham ido acompanhar a Copa do Mundo. Dessa maneira se pôde destacar os seguintes tipos de interação: pessoal, relativo às pessoas que frequentaram as Fan Fests ${ }^{\mathrm{TM}}$, e a maneira como elas se comportavam; a interação com o som; e a interação com a imagem da tela.

No que diz respeito à interação pessoal, se pode separar as pessoas que assistem aos jogos na Fan Fest ${ }^{\mathrm{TM}}$ como sendo caracterizados ou neutros. Os caracterizados são aqueles que vão assistir aos jogos vestidos com as cores da seleção pela qual vão torcer, e a quantidade de adereços e símbolos nacionais vai da paixão e possibilidade de cada um. Normalmente estão organizados em grupos, e mesmo para nascidos na África do Sul vestir a camisa de uma seleção que não sejam a Bafana Bafana não é um absurdo. O país, além de não ter tradição no futebol, também é um lugar que atraiu muitos imigrantes de diferentes partes do planeta, em sua maioria ingleses, holandeses, portugueses e indianos, e a pluralidade de países é uma oportunidade para alguns expressarem o seu sentimento de identificação com outro país.

Um jovem, parte de um grupo que assistia ao jogo da Inglaterra sentado em cima de uma grande bandeira de São Jorge, disse:

Eu e meus amigos só torcemos para a Inglaterra, a maioria nasceu aqui na África do Sul ou veio muito novo, mas nos sentimos todos ingleses, nossas famílias são de origem inglesa, por isso torcemos para eles. (Shawn, África do Sul). 
$\mathrm{Na}$ medida em que há torcedores caracterizados, é possível que esteja presente o seu rival direto, isto é, seu opositor na partida. Desse modo, uma pessoa vestida com as cores do seu time de predileção não só torce pelo bom resultado - comemora, sofre, pula, grita e gesticula com os lances do jogo -, mas também provoca os seus adversários, seja diretamente, com frases ou músicas de provocação, ou com o próprio sucesso do time oponente. Para haver rivalidade é preciso que o grau de intensidade com que o torcedor vive os sucessos e fracassos do time sejam altos. Durante a Copa de 2010, a presença nas Fan Fests ${ }^{\mathrm{TM}}$ era sobretudo de sul-africanos, e, apesar de escolher uma equipe para torcer, eles não faziam com intensidade suficiente para haver rivalidade. No entanto, em alguns casos foi possível ver esse confronto ritualizado. Torcedores de Brasil e Argentina, e Inglaterra e Alemanha quando se encontravam na Fan Fest ${ }^{\mathrm{TM}}$ trocavam provocações. Apesar de não terem jogado um contra o outro, a rivalidade entre esses times é histórica e só a presença um do outro em uma competição é suficiente para atiçá-la.

Destacam-se dois eventos relativos à interação entre torcedores rivais. Três jogos estavam agendados para o dia 18 de junho, o primeiro deles era entre a Alemanha e Sérvia, o segundo entre Eslovênia e Estados Unidos, o último entre Inglaterra e Argélia. Torcedores ingleses que estavam lá desde o primeiro jogo foram se animando com a apresentação da Sérvia contra seus rivais alemães, tendo por ápice o gol que deu vitória aos sérvios, quando jogaram cerveja para o alto. O resultado final motivou os presentes a torcerem contra os EUA que jogaram a partida seguinte, mas também contribuiu para que os alemães que estavam na Fan Fest ${ }^{\mathrm{TM}}$ ficassem também para torcer pelos argelinos contra os ingleses no último jogo. Outro caso de rivalidade foi visto no jogo entre Estados Unidos e Inglaterra, dois dos países que mais mandaram turistas para a Copa do Mundo, e, como não havia espaço para todos no estádio, os que foram assistir na Fan Fest ${ }^{\mathrm{TM}}$ deram continuidade à ritualização do confronto, reproduzindo os cantos dos estádios e provocações dentro da Fan Fest ${ }^{\mathrm{TM}}$.

Os torcedores neutros são classificados dessa maneira porque de início não se pode afirmar para quem estão dando seu apoio. Podem estar sozinhos ou em grupo, da mesma maneira que podem ter ido à Fan Fest ${ }^{\mathrm{TM}}$ por curiosidade, por ser próximo de casa, por gostar do clima de jogo, ou como um programa de família. De maneira geral, esses torcedores estão lá pelo entretenimento, querem ter sobretudo a sensação de lazer, sendo assim, aplaudem 
cada lance bonito - por vezes independentemente de qual seja a equipe -, podendo inclusive comemorar gols de times rivais e mudar a sua lealdade ao longo do jogo, caso a equipe escolhida não esteja atendendo às expectativas. A maioria dos sul-africanos poderiam ser enquadrados nesse grupo, não fosse o caso de jogos da própria seleção e de outras equipes da África, demonstrando um sentimento pan-africano.

O nosso país está agora recebendo muitas pessoas e precisamos dar o exemplo de união. Muita gente ainda vê o país como racista, e sei que algumas pessoas mais velhas não são da mesma opinião que eu, mas nós vamos torcer pela África do Sul e todos os países africanos. (Jane, África do Sul).

Assim, os espectadores ali presentes, independentemente do grupo em que estivessem incluídos, poderiam sociabilizar com as pessoas presentes. Dentre as diversas possibilidades, uma pessoa poderia interagir dentro do seu próprio grupo de conhecidos ou com outro grupo de pessoas tendo como base o futebol e o interesse por um time em particular, provocando os adversários, celebrando a felicidade com o jogo e representando uma identidade de grupo. $\mathrm{Na}$ medida em que as Fan Fests ${ }^{\mathrm{TM}}$ eram grandes espaços abertos, elas funcionavam em alguma medida como um parque. Era possível ver famílias e crianças brincando, da mesma forma que alguns dos fãs que iam assistir aos jogos aproveitavam os intervalos entre as partidas para eles mesmos jogarem uma partida de futebol entre si, ou com pessoas que tinham conhecido ali mesmo.

Outra forma de interação entre as pessoas era a vuvuzela. Apesar de não ser uma forma verbal de comunicação, a produção de som com essa espécie de corneta significa, no cenário esportivo sul-africano, forma de apoio e expressão de sentimento. Além de tocarem todo o tempo praticamente, não raro se via a população local se expressando ritmicamente com as vuvuzelas, ou mesmo estrangeiros que tocavam os seus instrumentos por conta própria ou para fazer um diálogo com outros que haviam tocado.

No que diz respeito à interação com o som podemos separá-la entre a relação que a audiência tem com o áudio, ou seja, com a narração do que está sendo transmitido e as interações sonoras entre as pessoas. No caso do áudio pouco se pôde notar. O barulho feito pelas vuvuzelas abafava em muitos casos o entendimento da narração, além disso, se compararmos com a interação com o áudio feita no estudo de Gastaldo (2005), podemos ver que eram críticas 
as informações dadas, nesse caso, onde a plateia tem, ou se julga ter, mais informações sobre o jogo do que a própria rede de televisão. Tendo sido uma narração mais simples, sem comentários e repórteres de campo, e a qual se ouvia pouco, pode-se compreender a pouca interação com o áudio.

Em relação à interação sonora entre as pessoas, além do que já foi mencionado anteriormente sobre as vuvuzelas, é possível destacar os cânticos proferidos pelos sul-africanos em seus jogos, nos quais eles cantavam a parte em zulu do hino do país, e principalmente a canção Shosholoza. Com origem popular, essa música era cantada por trabalhadores das minas e o seu título é um termo de encorajamento e solidariedade entre os mineiros, e em contexto esportivo é cantada nos momentos de aperto.

Já no que concerne às imagens, foi possível notar que os presentes mudavam o seu comportamento reagindo ao que aparecia na tela. Em um dos casos, ovacionavam ou suspiravam quando jogadores celebridades apareciam por seus países, como por exemplo, Drogba, Cristiano Ronaldo, Messi, Kaká, ou mesmo que não estivesse em campo, como David Beckham. Outro caso era quando apareciam personalidades políticas como o presidente Jacob Zuma um misto de ovação e vaia - e o ex-presidente Nelson Mandela - muita festa. Os espectadores ainda interagiam com as imagens da partida, tal como estivessem acompanhando o jogo no estádio: lances de falta e de violência eram seguidos por uma interjeição de dor, lances perigosos, por suspiros de alívio ou ansiedade, cartões podiam ser seguidos por indignação ou apoio, dribles, por sorrisos e aplausos e o gol era festa.

\section{International FIFA Fan Fest ${ }^{\mathrm{TM}}$}

Depois do sucesso alcançado com a Fan Fest ${ }^{\mathrm{TM}}$ na Alemanha a FIFA anunciou que não só a África do Sul teria o evento. Para o presidente da FIFA, Joseph Blatter, "the first International FIFA Fan Fest is another milestone in bringing the excitement of the FIFA World Cup to an even greater audience" 7 (FIFA, 2009).

\footnotetext{
7 “A primeira International FIFA Fan Fest é mais um marco para levar a emoção da Copa do Mundo da FIFA para um público ainda maior.” (tradução minha).
} 
O objetivo na escolha das cidades (Berlim, Roma, Paris, Londres, Rio de Janeiro, Cidade do México e Sydney) foi cobrir os três principais fusos horários do globo, dando à Copa do Mundo uma sensação de um evento que acontece $24 \mathrm{~h}$ por dia. O critério que a FIFA usou para a seleção das cidades foi: a popularidade do futebol no país; a popularidade das cidades em receber turistas; a experiência das cidades em receber grandes eventos esportivos internacionais; a quantidade de pessoas na cidade que fossem de mercados futebolísticos fortes, como, por exemplo, Itália, Inglaterra e Brasil; a população da cidade, para saber se resultaria num grande número de espectadores frequentando a Fan Fest ${ }^{\mathrm{TM}}$. Sendo assim, a FIFA justificou as escolhas das cidades da seguinte forma: Roma é a cidade dos atuais campeões, Berlim foi onde aconteceu a primeira Fan Fest ${ }^{\mathrm{TM}}$, Paris e Londres são duas cidades cosmopolitas e multiculturais, o Rio de Janeiro será uma das sedes do próximo mundial, enquanto na América do Norte, a Cidade do México recebe o evento, e, para completar o globo, Sydney, representando a Austrália, onde o futebol tem crescido em interesse (FIFA, 2010b).

Tal como a Fan Fest ${ }^{\mathrm{TM}}$ na África do Sul, o evento internacional é organizado em parceria entre a FIFA e um comitê organizador local. Seguindo a mesma lógica, a FIFA oferece o telão, o apoio técnico e os planos e guias, enquanto a cidade fica responsável pela logística e infraestrutura necessária. A International Fan Fest ${ }^{\mathrm{TM}}$ contou com o patrocínio da Coca-Cola, Sony, Emirates e Hyundai/Kia. Outra diferença é que a transmissão do jogo, ao invés de estar com a $\mathrm{SABC}$, fica sob responsabilidade da emissora oficial do evento no respectivo país.

Para enriquecer a comparação entre a Fan Fest ${ }^{\mathrm{TM}}$ na África do Sul e as internacionais fez parte desta pesquisa um olhar sobre o evento ocorrido em Paris. A International FIFA Fan Fest ${ }^{\mathrm{TM}}$ sediada na capital francesa ficava nos Jardins do Trocadero (FIFA, 2010d). Ela tinha um formato retangular e os organizadores se aproveitaram disso para que no chão houvesse um tapete verde, imitando um campo de futebol - mais uma das estratégias para de se fazer sentir estar num estádio de verdade. Localizado no que seria uma das balizas estava a tela, tendo a torre Eiffel no fundo e, no que seria a baliza oposta, uma arquibancada para área VIP. Nas laterais do campo se multiplicavam lojas de produtos oficiais, comidas e bebidas; e no meio era o espaço para os espectadores. 
Faltando uma hora para o início do jogo, os jardins do Trocadero já estavam lotados, a entrada para a Fan Fest ${ }^{\mathrm{TM}}$ fechada e aqueles que não conseguiam lugar do lado de dentro sentavam do lado de fora da grade em espaços de onde era possível enxergar a tela gigante. Nas International FIFA Fan Fests $^{\mathrm{TM}}$ os patrocinadores oficiais do evento eram diferentes dos patrocinadores da iniciativa na África do Sul, e foram eles que organizaram as atividades que antecederam a final da Copa do Mundo. Um apresentador ia intercalando palavras de motivação para a plateia com apresentações que variavam desde música, malabarismos com bola, danças que tinham virado moda na África do Sul - desde que os artistas estivessem sempre usando os produtos da patrocinadora do evento -, até que por fim duas pessoas da plateia foram convidadas para se enfrentar num jogo de videogame - também da patrocinadora oficial - usando as equipes de Holanda e Espanha, e a partida ainda foi acompanhada de narração e comentários. Depois do virtual, foi o jogo real, e após a vitória da Espanha as pessoas saíram pela rua indo para casa, festejando a vitória ou só festejando estar de férias.

\section{Outras fan fests}

Se pensarmos na Fan Fest ${ }^{\mathrm{TM}}$ como um espaço público para assistir aos jogos, podemos ampliar esse conceito não apenas para os espaços oficiais da FIFA, mas para outras áreas. Na África do Sul, além das FIFA Fan Fests ${ }^{\mathrm{TM}}$ era possível assistir os jogos em grandes telas em diversos lugares que contavam inclusive com a autorização da FIFA e eram chamados de public viewings. Esses espaços eram organizados exclusivamente pela iniciativa privada, fossem patrocinadores do Mundial, como a Hyundai e a Coca-Cola, ou por centros comerciais, ou por cassinos, ou por uma associação de bares e restaurantes.

Segundo a responsável pela Fan Fest ${ }^{\mathrm{TM}}$ de Sandton, Jessica Lehr, a FIFA não vê essas public viewings como uma competição ao seu evento. Para poder funcionar é preciso que seja dada uma licença de funcionamento, e alguns deles são organizados por outros patrocinadores da FIFA, que por contrato têm o direito de abrir uma public viewing.

Apesar de não serem eventos organizados com o selo oficial, eles se baseiam em ideais muito semelhantes, e, se levarmos em consideração os bares e clubes que transmitem jogos para os seus frequentadores, são, inclusive, 
iniciativas mais antigas. Assim, são alguns pontos que merecem reflexão. Em primeiro lugar, a tela onde se exibe o jogo de futebol pode não ser tão grande quanto a da FIFA Fan Fest ${ }^{\mathrm{TM}}$, o seu tamanho se adapta às dimensões do empreendimento. $\mathrm{O}$ palco associado à tela pode ou não existir, mas certamente $\mathrm{o}$ jogo não é a única oferta de entretenimento. De acordo com quem é o responsável pela organização, o tipo de lazer pré e pós-jogo pode mudar. Na África do Sul, bares, centros comerciais e restaurantes em sua maioria ofereciam música de diferentes estilos, mas havia também cassinos e, tal como na Fan Fest $^{\mathrm{TM}}$, jogos para promover a marca dos patrocinadores.

O contexto da África do Sul contribuiu para um relativo sucesso desses espaços, pois eles ofereciam um espaço mais protegido do frio que fazia no inverno, e onde as pessoas se sentiam mais seguras. Apesar de as Fan Fests ${ }^{\mathrm{TM}}$ contarem com segurança, eram espaços grandes, onde a entrada livre e o sentimento de medo da violência de quem vive e de quem não conhece o país afastava as pessoas. ${ }^{8}$ Dessa maneira, os public viewings serviam como uma oferta diferenciada para as Fan Fests ${ }^{\mathrm{TM}}$, por um lado podiam não ter as mesmas dimensões e atrações, mas por outro ofereciam um local mais acolhedor e mais seleto.

Para um torcedor mexicano em um centro comercial de Johanesburgo, havia alguns motivos para preferir assistir ao jogo lá:

Não há nada como ir ao estádio, mas ver os jogos aqui é muito legal. É seguro, é um lugar bonito, eles oferecem aquecimento, tem outras pessoas para assistir aos jogos, torcedores de outros países... (Fred, México).

Na verdade, é esse lado do consumo que é interessante de se analisar nas public viewings. Nas FIFA Fan Fests ${ }^{\mathrm{TM}}$ a questão do consumo está muito bem marcada, mas caso a pessoa deseje é possível passar um jogo todo sem consumir nada, enquanto nas public viewings o ingresso está relacionado ao consumo, que também funciona como forma de diferenciação. Nas public viewings a entrada só é gratuita quando patrocinada exclusivamente por uma grande

\footnotetext{
8 Funcionários dos hotéis expressavam que era preciso muita cautela ao se locomover nas cidades, principalmente Johanesburgo, e que a Fan Fest ${ }^{\mathrm{TM}}$ de Soweto, principalmente, deveria ser evitada. Alguns entrevistados nas public viewings também justificavam a escolha com base na sensação de segurança oferecida.
}

Horizontes Antropológicos, Porto Alegre, ano 19, n. 40, p. 201-230, jul./dez. 2013 
companhia, como o caso da Hyundai e da Coca-Cola, nos outros casos ou a entrada já é cobrada, ou é feita a partir do consumo. Os estabelecimentos só disponibilizam mesas para quem consumir, ou então é cobrado um consumo mínimo para estar no lugar, ou em outros casos a entrada é um valor preestabelecido à parte do consumo em bebidas e comida.

Não é novidade que o consumo sirva como forma de diferenciação social (García Canclini, 1996), e na medida em que o consumo é um componente presente nesses estabelecimentos, é fácil para quem frequenta esses espaços poder perceber qual vai ser a frequência do local e poder escolher de acordo com as suas preferências sociais. As grandes companhias transnacionais se interessam pelos grandes mercados, por isso permitem e incentivam a entrada do maior número de pessoas possível, enquanto organizações privadas locais têm um escopo comercial menor e agem de acordo com o seu target de mercado, selecionando o seu grupo de frequentadores a partir dos gastos e consumo que eles podem fazer. Mas é importante notar que, seja feito pela FIFA ou por outras organizações, o consumo é indispensável.

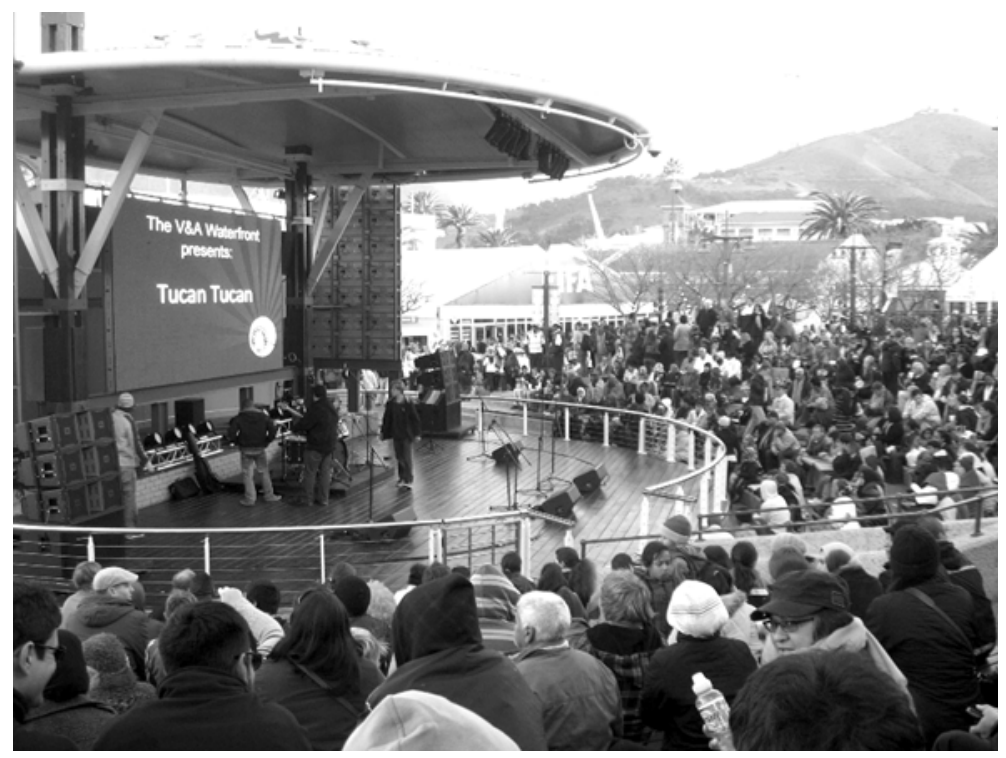

Figura 7. Public viewing no centro comercial V\&A Waterfront, na Cidade do Cabo. 


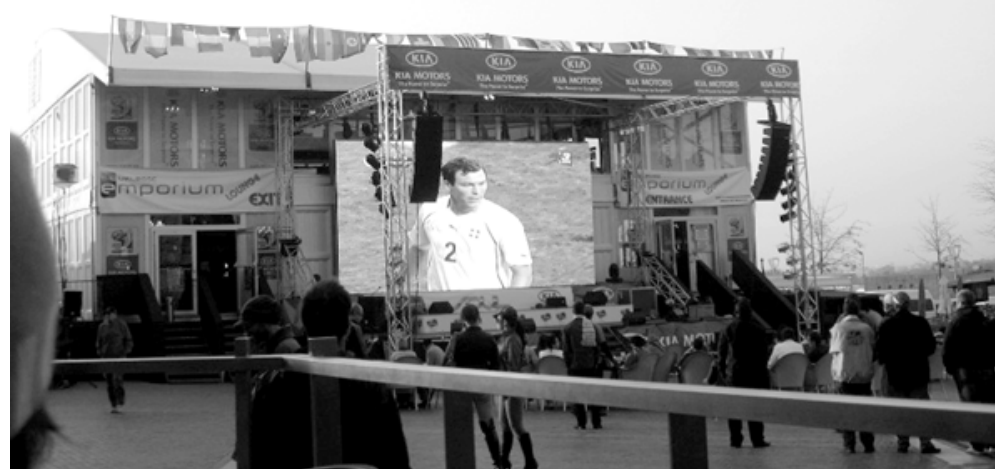

Figura 8. Public viewing da Hyundai/Kia localizada em uma das pracas de alimentação de Melrose Park e ao lado de clube noturno.

\section{Conclusão}

Independentemente de o fluxo de pessoas ter sido inferior do que na Alemanha, o sucesso das Fan Fests ${ }^{\mathrm{TM}}$ na África do Sul pode ser medido pela continuação do projeto, prevista para $2014,{ }^{9}$ e da mesma forma que houve diferenças da Alemanha para África do Sul, o mesmo acontecerá no Brasil. Outra medida de sucesso é a implementação de outros espaços semelhantes para se assistir aos jogos, sejam centros comerciais, bares, ou public viewings.

O que se pode afirmar é que do ponto de vista da FIFA, as Fan Fests ${ }^{\text {TM }}$ são um empreendimento com baixos riscos e altamente controlado. Segundo Matheson (2006), os maiores custos de um evento desse tipo são com segurança e transporte, e de acordo com a separação de tarefas essa parte é responsabilidade do comitê local. Os altos valores conseguidos com a exploração

9 Informação dada por Jessica Lehr em entrevista.

Horizontes Antropológicos, Porto Alegre, ano 19, n. 40, p. 201-230, jul./dez. 2013 
televisiva de eventos esportivos fez com que as instituições do esporte reconsiderassem parte do seu papel e decidissem ter mais controle na utilização das suas imagens (Boyle; Haynes, 2004). Dessa maneira, ao aumentar o controle sobre o evento, a FIFA pode tentar maximizar os seus lucros. Considerando a quantidade de imagens geradas pelas televisões e espalhadas pelo mundo, e que o objetivo principal é o marketing, pode-se concluir que há sucesso na iniciativa.

Para os espectadores, a socialização é um ponto importante nas Fan Fests $^{\mathrm{TM}}$ e outras public viewings, mas pelo viés da organização o que se nota é uma tentativa de recriar um espaço que seja semelhante ao estádio em termos de experiência. Seja como experiencial commodities ou como simples estratégia de marketing, o que se nota é que a comercialização é um forte motor de transformação na forma como as pessoas se relacionam com o esporte. $\mathrm{O}$ curioso é que mesmo os espaços esportivos tradicionais, como os estádios, têm se modificado seguindo uma comodificação e espetacularização dos eventos culturais.

Tendo em vista o objetivo primariamente exploratório desta pesquisa, e considerando a realização do próximo mundial no Brasil, saliento alguns temas que poderão ser aprofundados. Primeiramente, desenvolver estudos de recepção que permitam aferir os usos, interesses e a forma como o evento é recebido e interpretado pelo público. Em segundo, dar atenção à produção dos espaços, tendo em vista as estratégias para recriar o estádio utilizando novas tecnologias - seja com o som estéreo, imagem em alta definição, e agora a transmissão em 3D. Em terceiro lugar, avaliar como a prática esportiva vem sendo transformada por parâmetros comerciais, substituindo traços tradicionais da cultura por formas de espetacularização do esporte, e associar como esses processos estão ligados à Copa do Mundo e aos Jogos Olímpicos no Brasil.

\section{Referências}

BAUMAN, Z. Globalização: as consequências humanas. Rio de Janeiro: Jorge Zahar, 1999.

BOYLE, R.; HAYNES, R. Football in the new media age. London: Routledge, 2004.

Horizontes Antropológicos, Porto Alegre, ano 19, n. 40, p. 201-230, jul./dez. 2013 
COLVILE, R. From 'Big Owe' to pure profit. The Observer, 15 ago. 2004. Disponível em: <http://www.guardian.co.uk/business/2004/aug/15/ olympics2012.theobserver>. Acesso em: 15 fev. 2012.

DAYAN, D.; KATZ, E. Media events. London: Harvard University Press, 1992.

FEATHERSTONE, M. (Ed.). Global culture. London: Sage, 1990.

FEATHERSTONE, M. Consumer culture and postmodernism. London: Sage, 1991.

FIFA. FIFA Fan Fest goes global for the first time. 2009. Disponível em: $<$ http://www.fifa.com/worldcup/organisation/media/newsid=1138797/index. html>. Acesso em: 5 fev. 2010.

FIFA. FIFA Fan Fest: a global platform which unites the world, 2010a. Disponível em: <http://www.fifa.com/worldcup/organisation/fanfest/intro. html>. Acesso em: 15 maio 2010.

FIFA. FIFA Fan Fest ${ }^{\mathrm{TM}}$ - frequently asked questions. 2010b. Disponível em: $\quad<$ http://www.fifa.com/mm/document/tournament/fanfest/01/14/09/88/ fifafanfest-faqs.pdf $>$. Acesso em: 15 maio 2010.

FIFA. FIFA Fan Fest ${ }^{\mathrm{TM}}$ information pack. 2010c. Disponível em: <http:// www.fifa.com/mm/document/tournament/fanfest/01/20/88/48/fifafanfest_ infopack.pdf $>$. Acesso em: 15 maio 2010.

FIFA. FIFA Fan Fest ${ }^{\mathrm{TM}}$ : international: Paris. 2010d. Disponível em: $<$ http:// www.fifa.com/worldcup/archive/southafrica2010/organisation/fanfest/ international/cities/city=1030/index.html > . Acesso em: 15 maio 2010.

GAFFNEY, C.; MASCARENHAS, G. The soccer stadium as a disciplinary space. Esporte e Sociedade, n. 1, p. 1-16, nov. 2005/fev. 2006.

GARCÍA CANCLINI, N. Consumidores e cidadãos. Rio de Janeiro: Editora da UFRJ, 1996.

GASTALDO, E. "O complô da torcida": futebol e performance masculina em bares. Horizontes Antropológicos, ano 11, n. 24, p. 107-123, 2005. 
GIULIANOTTI, R. Sport, a critical sociology. Cambridge: Polity, 2005.

HALL, S. A identidade cultural na pós-modernidade. Rio de Janeiro: DP\&A, 2006.

HORNE, J. Sport in consumer culture. Basingstoke: Palgrave, 2006.

HORNE, J.; MANZENREITER, W. Football World Cup finals on the host countries Japan/Korea accounting for mega-events: forecast and actual impacts of the 2002. International Review of Sociology of Sport, v. 39, n. 2, p. 187-203, 2004.

HORNE, J.; MANZENREITER, W. An introduction to the sociology of sports mega-events. In: HORNE, J.; MANZENREITER, W. Sport mega-events. Oxford: Blackwell Publishers, 2006, p. 1-24, 2006.

MATHESON, V. Mega-events: the effect of the world's biggest sporting events on local, regional, and national economies. Worcester: College of the Holy Cross, 2006. (Department of Economics Faculty Research Series, Paper n. 06-10).

ROCHE, M. Mega-events and modernity: Olympics and expos in the growth of global culture. London: Routledge, 2000.

ROCHE, M. Mega-events, time and modernity: on time structures in global society. Time and Society, v. 12, p. 99-126, 2003.

TRAVANCAS, I. Fazendo etnografia no mundo da comunicação. In BARROS, A.; DUARTE, J. (Org.). Métodos e técnicas de pesquisa em comunicação. São Paulo: Atlas, 2006. p. 98-109.

UEFA CHAMPIONS FESTIVAL in Madrid. 14 maio 2010. Disponível em: $<$ http://www.uefa.com/MultimediaFiles/Download/PressRelease/uefaorg/ MediaReleases/01/48/83/04/1488304_DOWNLOAD.pdf>. Acesso em: 15 fev. 2012. 